\title{
複曲率曲げを受ける合成梁の挙動に関する基礎的研究 \\ BASIC STUDY ON BEHAVIOR OF COMPOSITE BEAM SUBJECTED TO DOUBLE CURVATURE BENDING
}

\author{
松田頼征*，笠井和彦**，酒井新吉***，元結 正次郎**** \\ Yoriyuki MATSUDA, Kazuhiko KASAI, Shinkichi SAKAI \\ and Shojiro MOTOYUI
}

\begin{abstract}
Composite beam has higher rigidity and strength than steel beam in the case of positive bending, and is considered to be the steel beam otherwise. Because of this, a composite beam in double curvature becomes complicated, since it consists of two portions of different length, stiffness, and strength. This paper proposes a practical analysis method that can clarify such a double curvature composite behavior in detail. The method is used to clarify elasto-plastic behavior of the composite beam by referring to various nonlinear effects from its elements such as steel beam, concrete slab, and stud connector.
\end{abstract}

Keywords : Composite beam, Multi-spring model, FEM analysis, Elasto-plastic response, Double curvature 合成梁, マルチスプリングモデル, FEM 解析, 弾塑性応答, 複曲率曲げ

1. はじめに

\section{1 背景}

鋼構造建物における合成梁では、正曲げで合成効果によりコンク リートスラブ（以下、スラブ）に圧縮軸力が生じるため、その剛性 と耐力は鉄骨梁よりも高く、負曲げでは早期にスラブの引張破壊が おこるため鉄骨梁と同等にみなされている。

よって架構に層間変形が生じると、図 1 のように合成梁には正・ 負曲げの二つの区間ができ、それらの異なる剛性により、異なる曲 げモーメント分布や区間長さが生じる。また、様々な荷重レベルで スラブの引張・圧縮破壊、鉄骨梁の降伏、スタッドコネクタ（以下、 スタッド）のずれや降伏など、それぞれの区間で異なる非線形挙動 がおこり、その相互作用により合成梁の変形と力が支配される。

既往の研究としては、両区間で異なる剛性を考慮した解析法の提 案 1)や部材実験との比較 2)を行った井上らの研究、その実験結果を 解析で再現 ${ }^{3)} し た$ 石川らの研究、1 層 3 スパンの架構を想定した実 験に基づき合成梁および全体架構の性状の考察を行なった山野辺ら の研究 $\left.{ }^{4}\right)$ が挙げられる。また、大規模な架構の実験報告 5 )-8)卒どもあ るが、正・負曲げでの耐力や歪の相違を示すことに留まっている。 その他の複曲率曲げの検討は、横座屈挙動に関するものが多い。以

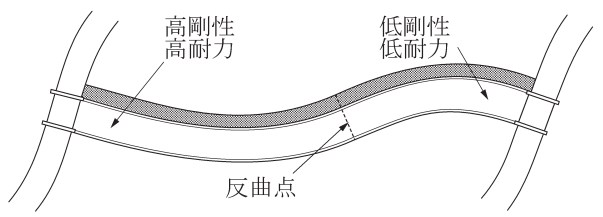

図 1 任意のスパンにおける合成梁・柱・接合部の変形
上のように、前述した非線形挙動の相互作用を包括的に分析した研 究は、著者らが知る限り行われていない。

なお、単曲率曲げの検討は、複曲率曲げに比べ、非常に多く行わ れてきたが(例えば文献 9)、正・負曲げ区間長さが一定であるため、 合成梁の検討手段としては限られると言える。正負同等の片持ち梁 変位を与えると、正曲げ区間が変形し難く負曲げ区間が変形し易い ことを再現しないため、歪や応力が、ひいては接合部破断の傾向も、 複曲率曲げの実際の場合と異なる可能性がある。

\section{2 本論文の目的と構成}

以上より本論文の目的は、複曲率曲げを受ける合成梁の挙動の解 析に有用な解析法を提示することと、それにより複曲率曲げを受け る合成梁の複雑な全体・局所挙動を明らかにすることである。

提案する解析モデルは、実務で良く用いられる線材要素とマルチ スプリング要素により、合成梁の構成要素である鉄骨梁・スラブ・ スタッドの応力・歪を再現するものであり、既往実験や詳細な有限 要素解析を用いてその精度を検証する。梁端および材長方向におけ る各構成要素の応力・歪を分析することで、1.1 節に述べた正・負 曲げの両区間の相互作用がおよぼす影響を包括的に論ずる。さらに、 損傷が集中寸る梁端下フランジの歪に関した力学的考察とパラメト リックスタディにより、合成梁の設計に有用な検討方法を提示する。

2 章では、複曲率曲げを受ける合成梁の既往実験の概要と、詳細 な有限要素モデル、および提案する解析モデルの概要を示す。3 章 では、解析により実験の挙動が正確に模擬できることを示した上で、 実験計測が行われなかった弾塑性挙動、局所挙動を、解析により検 討する。4 章では、合成効果による下フランジ歪の増減に関する簡
* 東京工業大学 大学院生 $\cdot$ 修士 (工学)

** 東京工業大学建築物理研究センター 教授・Ph.D

*** 東京工業大学 大学院生·工修 (伊藤忠テクノソリューションズ(株)

**** 東京工業大学人間環境システム専攻 教授・工博
Grad. Stud., Tokyo Institute of Technology, M.Eng.

Prof., Str'l Eng. Research Center, Tokyo Inst. of Technology, Ph.D.

Grad. Stud., Tokyo Institute of Technology, M.Eng.

(Itochu Techno-Solutions Corporation)

Prof., Dept. of Built Environment, Tokyo Institute of Technology, Dr.Eng. 
易評価式を提案する。合成梁の両区間の曲げ剛性の相互関係は、梁 に接続する柱の回転拘束効果にも影響されるため、5 章では、これ も含めたパラメトリックな検討により、正曲げで増大寸ると言われ てきた合成梁の下フランジ歪について議論する。

\section{2. 既往実験および解析モデルの概要}

\section{1 井上らの実験概要}

文献 2)の合成梁実験の概要を示す。なお、各諸元值はSI 単位に換 算したものである。図 2 に対象と寸る合成梁、図 3 に合成梁断面、 表 1 に各試験体の名称と概要をそれぞれ示す。左右梁端に時計回り

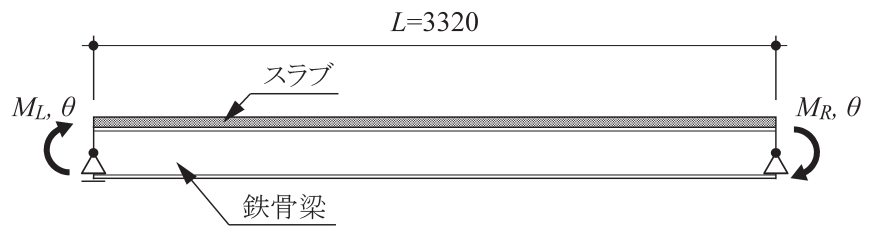

図 2 対象の合成梁及び左右梁端の変形角とモーメントの定義

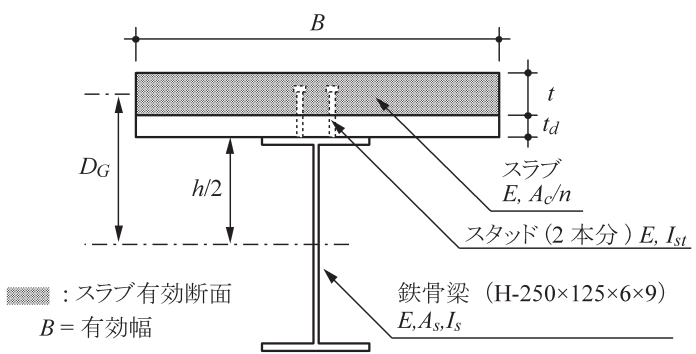

図 3 合成梁断面

表 1 各試験体のスラブ形状と 図心間距離

\begin{tabular}{|c|c|c|c|}
\hline $\begin{array}{c}\text { 試験体 } \\
\text { 名称 }\end{array}$ & $\begin{array}{c}t_{d} \\
(\mathrm{~mm})\end{array}$ & $\begin{array}{c}t \\
(\mathrm{~mm})\end{array}$ & $\begin{array}{c}D_{G} \\
(\mathrm{~mm})\end{array}$ \\
\hline $\mathrm{CB} 5 \mathrm{D}$ & 25 & 50 & 175 \\
\hline $\mathrm{CB} 5 \mathrm{~S}$ & 0 & 50 & 150 \\
\hline $\mathrm{CB} 10 \mathrm{~S}$ & 0 & 100 & 175 \\
\hline $\mathrm{CB} 0$ & - & - & - \\
\hline
\end{tabular}

※ 試験体 CB0 は純鉄骨試験体

表 3 コンクリートの 材料特性

\begin{tabular}{|c|c|c|}
\hline $\begin{array}{c}E_{c} \\
\left(\mathrm{kN} / \mathrm{mm}^{2}\right)\end{array}$ & $\begin{array}{c}F_{c} \\
\left(\mathrm{~N} / \mathrm{mm}^{2}\right)\end{array}$ & $\begin{array}{c}F_{t} \\
\left(\mathrm{~N} / \mathrm{mm}^{2}\right)\end{array}$ \\
\hline 22.3 & 28.0 & 2.80 \\
\hline
\end{tabular}

表 5 鉄骨梁の各種性能

\begin{tabular}{|c|c|c|c|c|c|}
\hline $\begin{array}{c}\text { 断面積 } \\
A_{s}\left(\mathrm{~mm}^{2}\right)\end{array}$ & $\begin{array}{c}\text { せん断 } \\
\text { 断面積 } \\
A_{s h}\left(\mathrm{~mm}^{2}\right)\end{array}$ & $\begin{array}{c}\text { 断面2 次 } \\
\text { ーメント } \\
I_{s}\left(\mathrm{~mm}^{2}\right)\end{array}$ & $\begin{array}{c}\text { 降伏軸力 } \\
N_{s y}(\mathrm{kN})\end{array}$ & $\begin{array}{c}\text { 降伏 } \\
\text { モメント } \\
M_{s y}(\mathrm{kN} \cdot \mathrm{m})\end{array}$ & $\begin{array}{c}\text { 全塑性 } \\
\text { モメント } \\
M_{s p}(\mathrm{kN} \cdot \mathrm{m})\end{array}$ \\
\hline 3697 & 1392 & 39600000 & 1129 & 97 & 107 \\
\hline
\end{tabular}

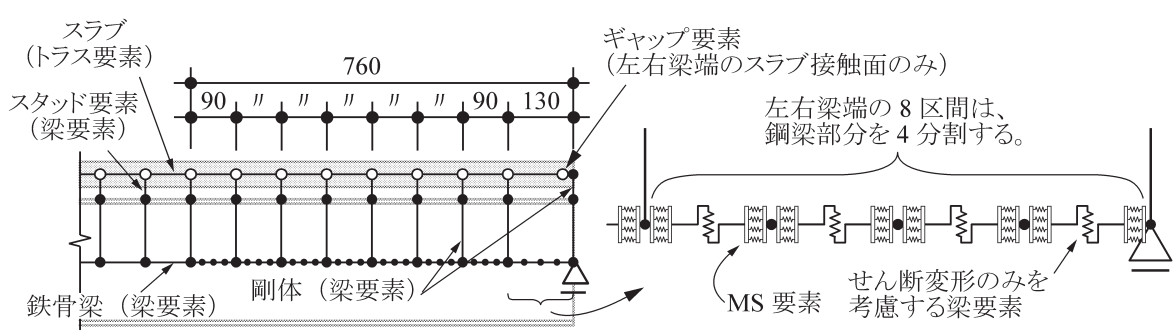

(a) 全体図
表 2 鋼材の材料特性

\begin{tabular}{|c|c|c|}
\hline \multirow{2}{*}{$\begin{array}{c}E \\
\left(\mathrm{kN} / \mathrm{mm}^{2}\right)\end{array}$} & \multicolumn{2}{|c|}{$\begin{array}{c}F_{y} \\
\left(\mathrm{kN} / \mathrm{mm}^{2}\right)\end{array}$} \\
\cline { 2 - 3 } & フランジ & ウェブ \\
\hline 205 & 0.295 & 0.334 \\
\hline
\end{tabular}

表 4 スタッド2 本分の 降伏せん断力 $q_{y}$ 初期ずれ剛性 $K_{s t}$

\begin{tabular}{|c|c|c|}
\hline & $\begin{array}{c}q_{y} \\
(\mathrm{kN})\end{array}$ & $\begin{array}{c}K_{s t} \\
(\mathrm{kN})\end{array}$ \\
\hline CB5D & 52.9 & 176 \\
\hline CB5S & 45.9 & 144 \\
\hline CB10S & 78.7 & 243 \\
\hline
\end{tabular}

を正とするモーメント $M_{L}, M_{R}$ 、および等しい変形角 $\theta$ が作用する場 合を考える。試験体は、合成梁 3 体と純鉄骨梁 1 体であり、鉄骨梁 部分は H-250×125×6×9 を有する。コンクリートスラブ（以下、スラ ブ）は、幅 $1500 \mathrm{~mm}$ であり、梁端部の幅 $300 \mathrm{~mm}$ のエンドプレート に接触するように配置されている。鉄筋はD10@90、デッキプレー ト(AK36)のリブは梁材長方向と直交する。合成梁試験体は、スラブ のデッキ溝深さ $t_{d}$ と等厚部厚さ $t$ をパラメータにしている (表 1 )。 表 2 と表 3 に鋼材とコンクリートの材料試験結果、表 4 にスタッド コネクタ（以下、スタッド） 2 本分の初期ずれ剛性 $K_{s t}$ と 0.85 倍の 最大耐力 $q_{y}$ を示す。表 5 に鉄骨梁の各種性能を示す。断面積 $A_{s}$ と断 面 2 次モーメント $I_{s}$ は公称值、せん断断面積 $A_{s h}$ はウェブの断面積、 降伏軸力 $N_{s y}$ 、降伏モーメント $M_{s y}$ 、全塑性モーメント $M_{s p}$ は表 2 の 鋼材の降伏応力度から算出した。

\section{2 マルチスプリング要素と線材要素を用いた解析モデル}

図 4a的うに、鉄骨梁は、弾塑性挙動を詳細に再現するため、梁 端から梁せいの 3 倍程度の長さの区間では曲げ変形と軸変形を考慮 した長さのないマルチスプリング要素（MS 要素）と長さのあるせ ん断梁要素を繋いでモデル化している（図 4b)。MS 要素に等曲げモ 一メントが生じるが、スタッド区間を 4 分割することでモーメント の変化を再現する。図 5 のように、鉄骨梁断面はウェブを 8 個、上 下の各フランジを 1 個のバネで表した。この区間以外の鉄骨梁は曲 げ変形、軸変形、せん断変形を考慮した梁要素でモデル化している。

スタッドは曲げ変形を考慮した梁要素、スラブはトラス要素でモ デル化している。鉄骨梁とスラブの各要素はそれぞれの図心に配置 し、スタッドと鉄骨梁図心を剛体で繋ぐ。スタッドは文献 2)の実験 では 2 本ずつ配置されていたが、本解析ではスタッド 2 本分を 1 要 素としてスタッド要素と呼ぶ。左右梁端のスラブ接触面では、ギヤ ップ要素を用いて柱とスラブの支圧と離間を再現する。

\section{3 FEM モデル概要}

有限要素解析 (FEM) モデルを図 6 に示す。鋼部材とスラブは 4 節点シェル要素でモデル化し、スタッドは 2 節点梁要素を用いてモ デル化している。スラブを模擬するシェル要素はスラブ中立面に設 置され、鉄骨梁の上フランジ板の中立軸との間に設けた梁要素で接 合される(図 7a)。この梁要素にスタッドのせん断力とす心゙り量の関 係を持たせる。スラブ端と柱面との接触による力の伝達を表現する ため、3 組のダミーの梁要素グループを設置している(図 7b)。第 1 グループはスラブ端節点と柱面節点の間に設置し、引張方向には剛 性を持たず圧縮方向に高い剛性を持つ、いわゆるギャップ要素と同 等な働きを持たせ、鋼柱面の間の接触挙動を模擬する。第 2 グルー プは接触点における極端な応力集中を回避するために設置するもの である。スラブをシェル要素でモデル化しているため板厚方向の節

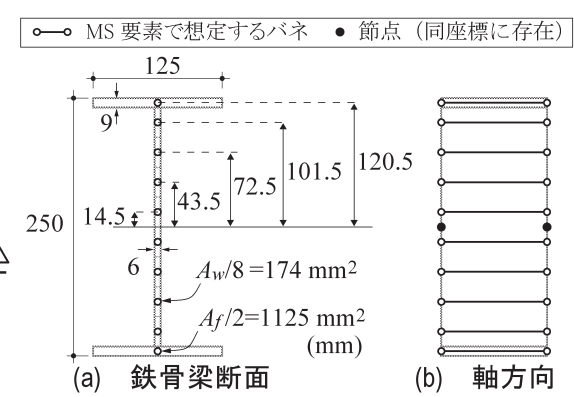

図 5 MS 要素で想定する鉄骨梁 


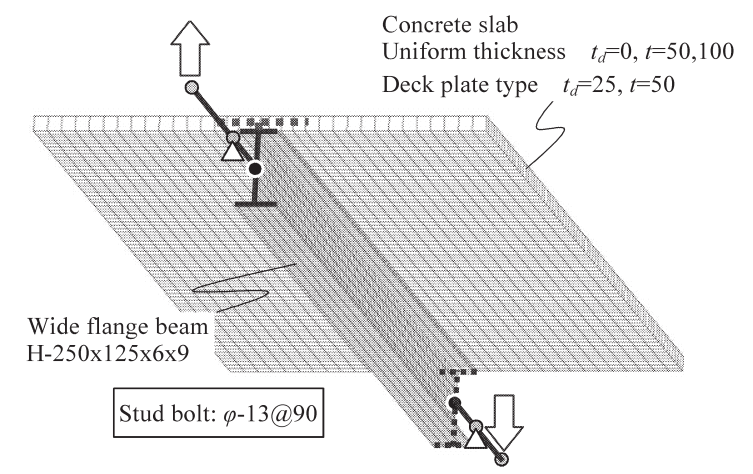

図 6 FEM モデル概要

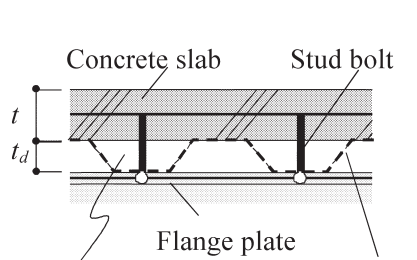

Neglect concrete Steel deck

(a) スタッドボルト

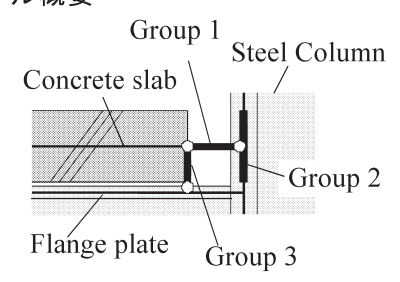

図 7 スラブと鋼架構の結合モデル化

点は 1 個となるが鋼柱面ではスラブからの圧縮力はスラブ厚分に作 用するものとして剛な領域として表現するもので、曲げに関しての み剛としている。本モデルでは、試験体端部の剛な治具および加力 用梁を剛な梁要素でモデル化している。第 3 グループはスラブが鉄 骨梁上フランジを貫通するのを防ぐために設置するものであり、引 張方向には剛性を持たず圧縮方向に高い剛性を持たせている。本モ デルの詳細は文献 10)を参照されたい。

\section{4 各定数の設定}

線材モデル（2.2 節）の鋼材、スタッド要素、コンクリートの各 構成則をそれぞれ図 $8,9,10$ に示す。図中の各定数は、文献 2)から 求めた表 $2,3,4$ の值を用いる (2.1 節)。図 8 の $\alpha$ は、3 章で後述す る純鉄骨試験体の実験結果と解析結果で良い対応を示す值を模索し て $\alpha=0.02$ とし、図 9 のスタッド要素にもこの值を適用する。図 9 の $q$ はスタッド要素 1 本あたりに作用するせん断力、Slip は鉄骨梁上 フランジとスラブ図心とのずれを表す。表 6 亿線材モデルで用いる 各試験体の有効幅を示す。スラブをトラス要素で再現した既往文献 ${ }^{11)}$ において、設計指針 ${ }^{12)}$ の有効幅は、弹性剛性と耐力を過大に評価 すると指摘されている。これを踏まえて、本解析で用いる有効幅は、 付録の方法より、FEM 解析結果の鉄骨梁塑性開始時までの荷重変形

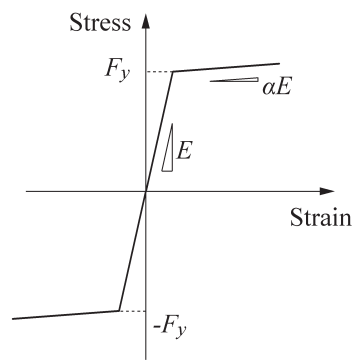

図 8 MS 要素における 鋼材の応力度 - 歪関係

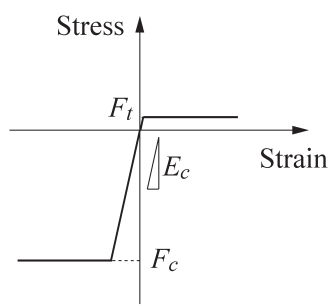

図 10 コンクリートの材料特性

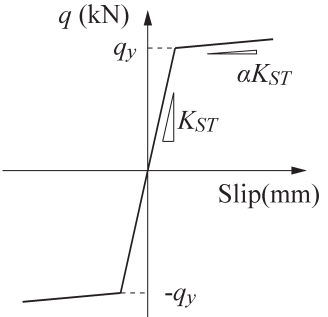

図 9 スタッド要素(スタッド 2 本分）のモデル化

$\begin{gathered}\text { 表 } 6 \text { FEM 解析から } \\
\text { 得た各試験体の } \\
\text { 解析有効幅 }\end{gathered}$
\begin{tabular}{|c|c|}
\hline $\begin{array}{c}\text { 試験体 } \\
\text { 名称 }\end{array}$ & $\begin{array}{c}\text { 解析有效幅 } \\
(\mathrm{mm})\end{array}$ \\
\hline $\mathrm{CB} 5 \mathrm{D}$ & 476 \\
\hline $\mathrm{CB} 5 \mathrm{~S}$ & 596 \\
\hline $\mathrm{CB} 10 \mathrm{~S}$ & 397 \\
\hline
\end{tabular}
得た各試験体の

関係が最小二乗法で合致するように定めた。本方法で定めた有効幅 は、設計指針 ${ }^{12)}$ から算出される值 $(789 \mathrm{~mm})$ の半分ほどであり、曲げ 剛性は 0.9 倍ほどになる。

FEM モデル(2.3 節)の各構成則について、鋼材は Overly Model (別 名 Sub-layer Model）を採用し、スタッド要素は弾性体、コンクリー 卜は図 10 に示したものとし、各詳細は文献 10)を参照されたい。

ここで、スラブを鉄筋とコンクリートの並列体と考えると、鉄筋 の寄与は、コンクリートが圧縮・引張強度に達するまでは小さく、 それ以降でも並列体の平面保持が崩れて小さいと考えられる。その ため鉄筋は無視した。さらに、コンクリートは、ひび割れによる剛 性低下を考慮す心゙きであるが、載荷の初期段階以外でその影響が僅 かであることを 2 つ解析モデルで確認し、解の収束性を確保する ために、図 10 に示すような完全弾塑性とした。

\section{3. 構成部材の弾塑性挙動と歪の局所挙動}

\section{1 実験結果の $M-\theta$ 関係による解析モデルの精度検証}

最初に、前節で述べた両解析モデルの精度を検証する。図 11 は純 鉄骨試験体および試験体 $5 \mathrm{D}, 5 \mathrm{~S}, 10 \mathrm{~S} の M_{L}-\theta, M_{R}-\theta$ 関係について実験 結果と解析結果を比較したものである。また、 $M-\theta$ 関係の代表値と して、コンクリートの引張強度前後に関わらず左右梁端の鉄骨梁が 弾性を保持する領域での最小二乗法から求めた荷重変形関係の傾き $K と \theta=0.02$ 時の耐力について両解析值（実験值に対する解析值の比

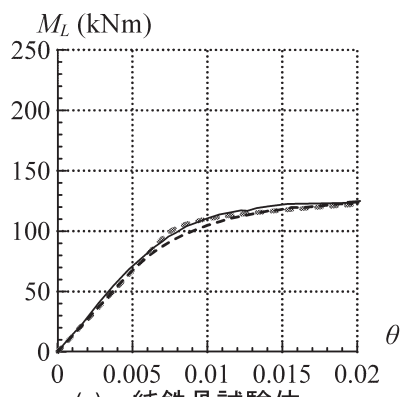

(a) 純鉄骨試験体

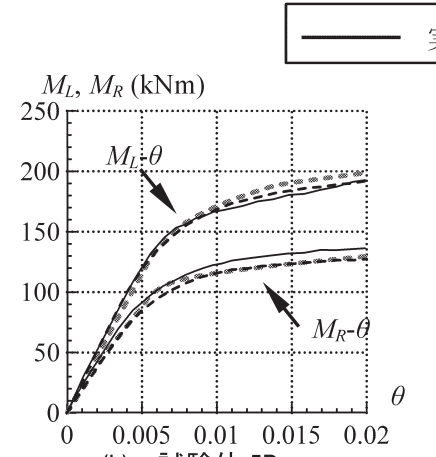

(b) 試験体 5D

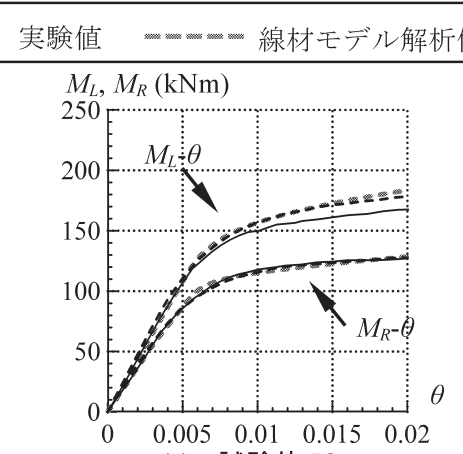

(c) 試験体 $5 \mathrm{~S}$

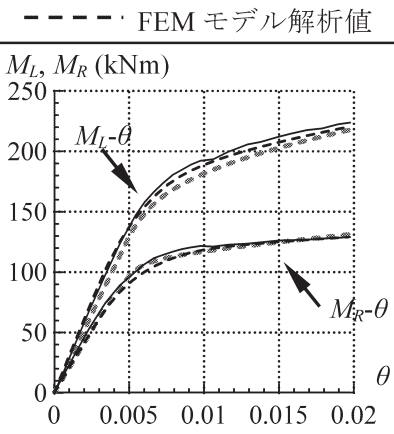

(d) 試験体 $10 \mathrm{~S}$

図 11 実験値と解析値の比較 
表 7 実験值に対する 2 種解析值の比率 （ $K$ と $\theta=0.02$ 時の耐力）

\begin{tabular}{|c|c|c|c|c|c|c|c|c|}
\hline \multirow{3}{*}{$\begin{array}{c}\text { 試験体 } \\
\text { 名称 }\end{array}$} & \multicolumn{4}{|c|}{ 線材モデル } & \multicolumn{4}{|c|}{ FEMモデル } \\
\hline & \multicolumn{2}{|c|}{$K$} & \multicolumn{2}{|c|}{$\theta=0.02$ 時耐力 } & \multicolumn{2}{|c|}{$\bar{K}$} & \multicolumn{2}{|c|}{$\theta=0.02$ 時耐力 } \\
\hline & 左側 & 右側 & 左側 & 右側 & 左側 & 右側 & 左側 & 右側 \\
\hline $5 \mathrm{D}$ & 0.95 & 0.92 & 1.05 & 0.95 & 1.00 & 0.86 & 1.00 & 0.93 \\
\hline $5 \mathrm{~S}$ & 0.99 & 1.01 & 1.10 & 1.02 & 1.09 & 1.06 & 1.06 & 1.00 \\
\hline $10 \mathrm{~S}$ & 0.90 & 0.94 & 0.97 & 1.02 & 1.06 & 0.92 & 0.98 & 1.00 \\
\hline
\end{tabular}

率として表示) を示したものが表 7 である。図 11 から、スラブが有 する剛性ならびに耐力への影響が異なるいずれの試験体においても 実験による $M-\theta$ 関係と $2 つ の$ 解析によるものはよく対応しているこ と、また、表 7 より、両モデルの解析值は、 $K$ と $\theta=0.02$ 時の耐力に おいて実験值との差異は 1 割程度であり、剛性・耐力共に高精度で 実験を再現していることが確認される。提案した線材モデルは、断 面力分布などの分析に最適であるため、次節以降では、この結果を 通して合成梁の局所的性状の詳細な分析を行うこととする。

\section{2 部材の状態変化と梁端での鉄骨梁・スラブの合応力の推移}

各試験体の弾性・塑性などの状態変化について、図 12 にその概要、 表 8 にそれらが生じた $\theta$ を示す。例として試験体 5D では、最初に 負曲げ区間のスラブが引張強度に達した後（図12 の(1)）、左右梁端 の下フランジがほぼ同時に降伏し (2) 、正曲げを受ける左端のスラ ブが圧縮強度に達して（3）、最後に負曲げを受ける右端のスタッド 要素が降伏せん断力に達した (4))。(3)の左端のスラブが圧縮強度に 達したのは試験体 5Dのみであり、これを除けば全ての試験体で同 じ順番で状態変化が生じた。試験体 5S では、(1)，(2)，(4)に加えて、 左端から離れた位置にあるスタッド要素が降伏せん断力に達した

(5)）。図 11 (3.1 節) のように各試験体の $M_{L^{-}} \theta, M_{R^{-}} \theta$ 関係は、 $\theta=0.005$ 付近で勾配が低下して、鉄骨梁の降伏の影響を大きく受けることが わかる。各部材の状態変化がおきた原因と影響を以下および次節以 降に示す。

まず、梁端における部材の状態変化（図 12 の(2)と(3)）とそれによ る影響を説明する。図 13 に合成梁断面における合成梁全体としての 鉄骨梁中心軸回りの曲げモーメント $M$ と各部位の合応力を示す。合 応力は、鉄骨梁の軸力 $N_{s}$, 曲げモーメント $M_{s}$, スラブの軸力 $N_{c}$ の 3 成分とし、スラブの曲げモーメントは無視する。また、左端での $N_{s}$, $M_{s}, N_{c}$ を $N_{L s}, M_{L s}, N_{L c}$ とする。正曲げと引張軸力を正、負曲げと圧縮 軸力を負とすると、 $M$ と各部位の合応力の釣合いは、

$M=M_{s}-N_{c} D_{G} \quad, \quad 0=N_{c}+N_{s}$

$(1 \mathrm{a}, \mathrm{b})$

として表され、式(1a)中の $N_{c} D_{G}$ が合成梁全体としての曲げモーメン

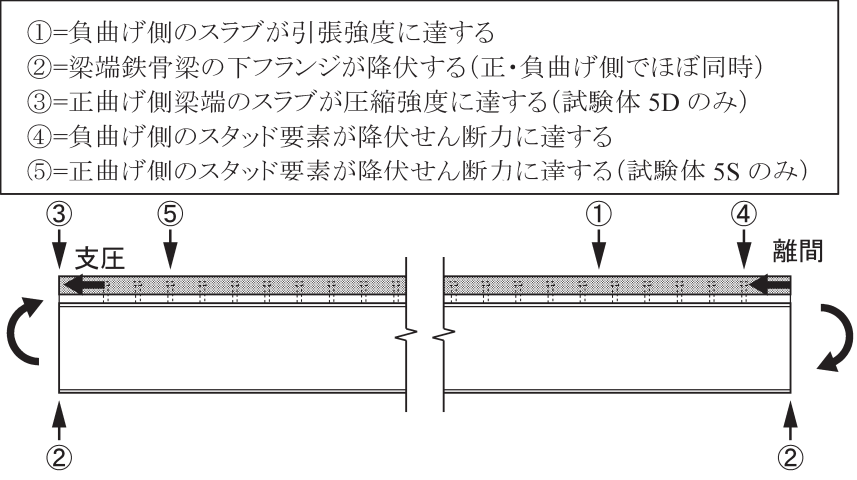

図 12 解析結果における弾性·塑性などの状態変化の概要

表 8 各試験体における状態変化が生じる $\theta$

\begin{tabular}{|c|c|c|c|}
\hline & 試験体 5D & 試験体 5S & 試験体 10S \\
\hline (1) & 0.0025 & 0.0030 & 0.0032 \\
\hline (2) & 0.0054 & 0.0053 & 0.0050 \\
\hline (3) & 0.0140 & - & - \\
\hline (4) & 0.0190 & 0.0063 & 0.0175 \\
\hline (5) & - & 0.0179 & - \\
\hline
\end{tabular}

番号は図 12 参照、(2)は左端降伏時の $\theta$ を示している。

トに及ぼすスラブ寄与分となる。 そこで、左端について、線材モ デルによる解析結果を基に計算 した $N_{L c} D_{G}$ の推移を図 14 に示す。 なお、図中には同解析によって 得られた $M_{L s}, M_{L}$ も併せて示し ている。また、図 15 に左右梁端 鉄骨梁の $N_{L s}$ と $M_{L s}$ の相関関係

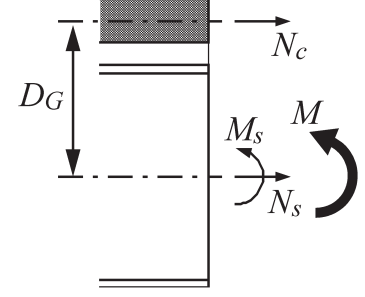

図 13 外力 $M$ と合応力の概要 を示す。それぞれが鉄骨梁の降伏軸力 $N_{s y}$ と全塑性モーメント $M_{s p}$ で基準化されている。全塑性曲線は、文献 ${ }^{13)}$ に基づく。

前述したように、梁端では全ての試験体で鉄骨梁がスラブに先行 して降伏する (図 14 中の(2))。そのときの $M_{L s}$ は 2.1 節で示した表 5 の鉄骨梁降伏モーメント $M_{s y}$ よりも小さい值となっている。これは、 図 13 に示したように合成梁における鉄骨梁は $N_{c}$ との釣合いによっ て $N_{s}$ が作用寸る梁柱部材として振舞うためであり、図 15 からもそ のことは明らかである。

鉄骨梁降伏以降の合応力の関係は、 $N_{c}$ の上昇に伴いこれと釣合う ベく $N_{s}$ は増加し続け、その結果として $M_{L s}$ は減少寸る。ただし、試 験体 5D の場合は、スラブが圧縮強度に達したため、 $M_{L s}$ が再度上昇 している (図 14 中の (3)以降)。本解析では圧縮強度以降でのスラブ 軸力を一定と仮定したために、(3)以降での $N_{L c} D_{G}$ は一定となり、 $M_{L s}$ がひずみ硬化によって増加する結果となっている。試験体 5D のス

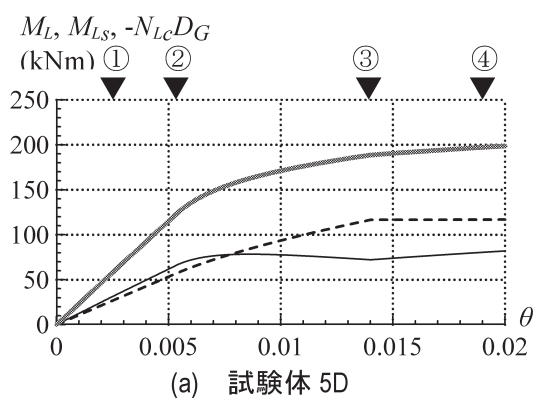

(a) 試験体 5D

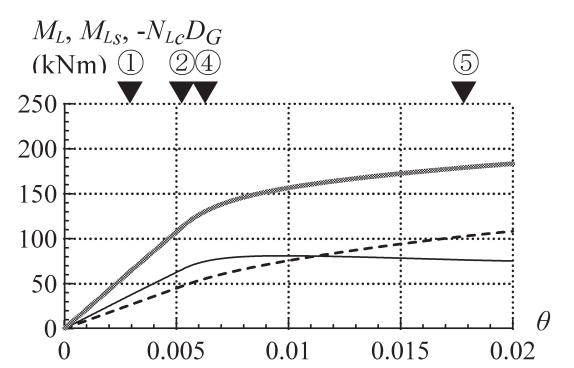

(b) 試験体 $5 S$

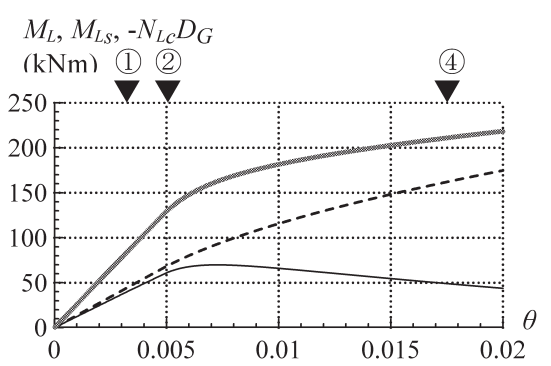

(c) 試験体 $10 \mathrm{~S}$

図 14 左端における外力 $M_{L}$ と $M_{L S 、} 、 N_{L C} D_{G}$ の推移（— $M_{L}-M_{L S}-\cdots-N_{L C} D_{G} ） ※$ 図中の番号は図 12 を参照 


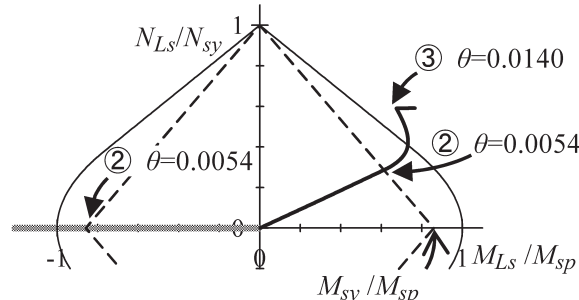

(a) 試験体 5D

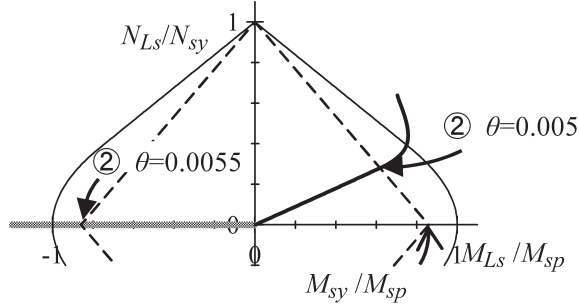

(b) 試験体 $5 \mathrm{~S}$

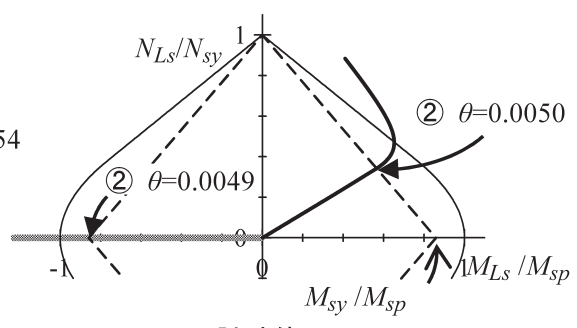

(c) 試験体 10S

図 15 解析から得られる鋼梁の NM 相関関係（黒い線=左端、灰色の線=右端） ※ 図中の番号は図 12 を参照

ラブが圧縮強度に達する結果となった理由は、図 13 から理解される ように、鉄骨梁降伏時での $M_{L}$ に対する $N_{L c} D_{G}$ がスラブ厚に比べて大 きいためである。すなわち、試験体 $5 \mathrm{D}$ は、他の 2 つの試験体と比 べると、スラブ厚に比し $D_{G}$ が大きく同じスラブ厚の試験体 $5 \mathrm{~S}$ より もスラブが有する剛性・耐力への影響が大きいためにスラブが圧縮 強度に至る結果となる。

図 15 中に示す $\theta$ は梁端での鉄骨梁とスラブの状態変化の生じる時 であり、各試験体の鉄骨梁は、負曲げを受ける右端と正曲げを受け る左端がほぼ同時に降伏することが分かる。この点については 4 章 にて詳しく説明する。

\section{3 鉄骨梁・スラブ・スタッドにかかるカの分布}

ここでは、材長方向における部材の状態変化とそれが及ぼす影響 について説明する。図 16 に試験体 $5 \mathrm{D}, 5 \mathrm{~S}, 10 \mathrm{~S}$ における $M_{s}, N_{c}, q$ の 分布を、スラブ引張強度時、左端鉄骨梁降伏時、 $\theta=0.02$ 時について 示す。また、 $\theta=0.02$ の鉄骨梁塑性域を灰色の破線、 $M_{s}$ 分布には $M_{L}$ と $M_{R}$ をシンボルで表示する。図の横軸は左端を原点として梁長さ $L$ で基準化した梁位置である。図 $16 \mathrm{a} \sim \mathrm{c}$ の上段と中段より、鉄骨梁降 伏後では反曲点の移動によって（4.1 節で後述）、 $M_{s}$ と $N_{c}$ がゼロに なる位置が右端側に移動する。 $M_{s}$ と $N_{c}$ の值は、引張強度に至った
断面の $N_{c}$ を除いて、載荷の進行によって概衩増加し続ける。負曲げ 区間の $N_{c}$ は、右端ではスラブと梁端接触面の離間によってゼロとな り、右端から離れた断面で最大值をとり、引張強度に達する（図 12 の(1)）。なお、図11（3.1 節）と図 16 からわかるように、スラブが 引張強度に達しても、梁端の $M-\theta$ 関係と $M_{s}$ の分布に与える影響は 小さい。 $\theta=0.02$ (破線) について、左端から図中の灰色の破線まで の領域では、それよりも内側の領域よりも、 $M_{s}$ の傾きが小さく、 $N_{c}$ の傾きが大きい。これらの原因は、この領域では鉄骨梁が降伏した ために、 $M$ に対する $M_{s}$ が減少し、これに伴って $N_{c}$ が増大した（式 1a）ためである。鉄骨梁の塑性域については、次節で図示する。

図 $16 \mathrm{a} \sim \mathrm{c}$ の下段の $q$ 分布について述べる。ここで、 $N_{c}$ は $q$ の蓄積 による值であることから、次式の関係が成り立つ。

$$
q_{i}=N_{c, i}-N_{c, i-1}
$$

$q_{i}$ は左端から $i$ 番目のスタッド要素のせん断力、 $N_{c, i}$ は $i$ 番目のスタ ッド要素の右側に繋がるスラブ要素の軸力で、 $N_{c, 0}=N_{L c}$ である。前述 したように、鉄骨梁が塑性化した断面では $M_{s}$ が減少して $N_{c}$ が増大 する（式 1a）。つまり、鉄骨梁の塑性化の範囲が $i$ 番目のスタッド要 素までの場合、式(2)からこの部分で $q_{i}$ が大きくなることがわかる。

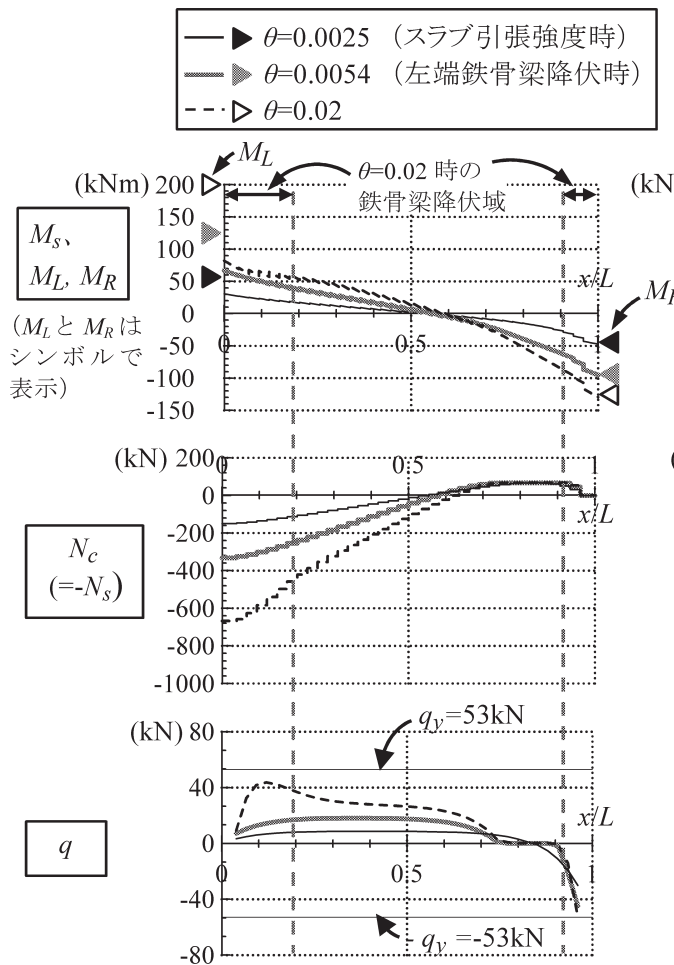

(a) 試験体 5D
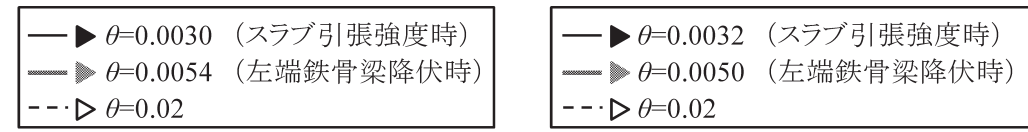

$(\mathrm{kNm}) 200$

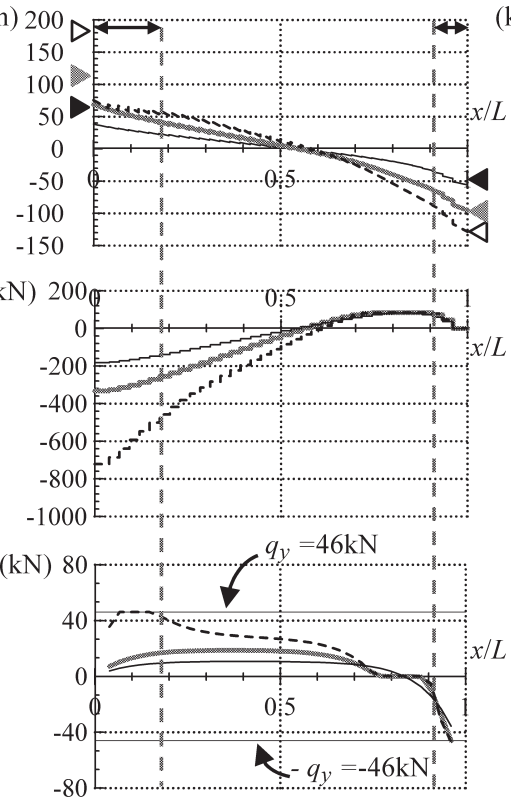

(b) 試験体 5S
図 $16 M_{s}, N_{c}, q$ の分布 $\left(\right.$ 上段 $=M_{s}$ 、中段 $=N_{c} 、$ 下段 $\left.=q\right)$

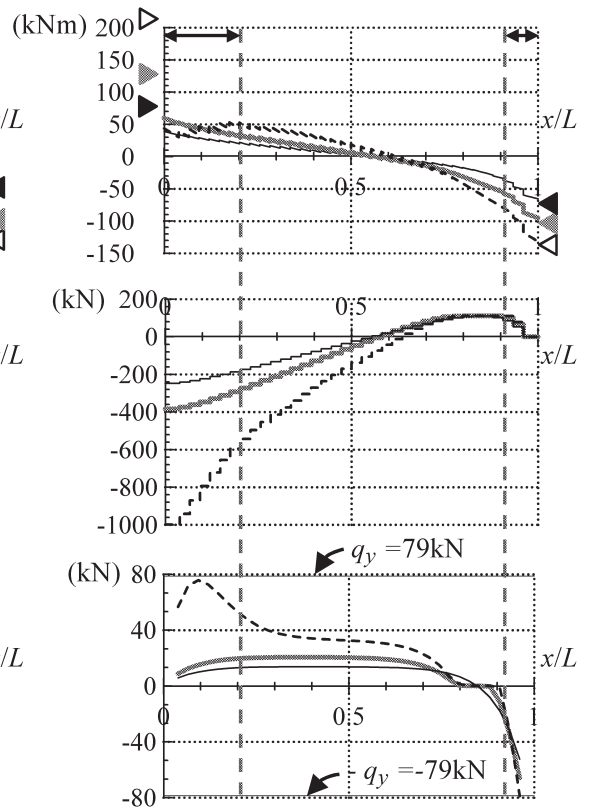

(c) 試験体 $10 \mathrm{~S}$ 


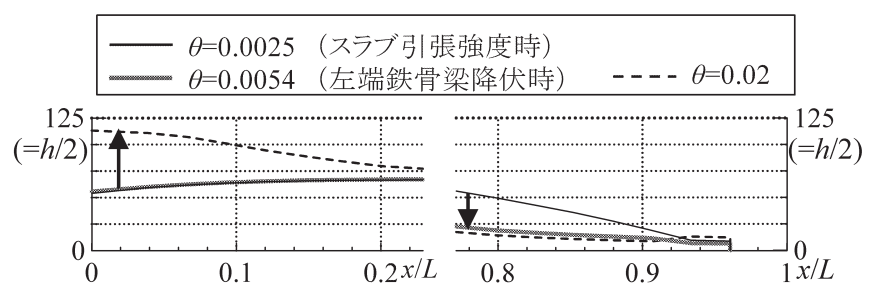

(a) 試験体 5D

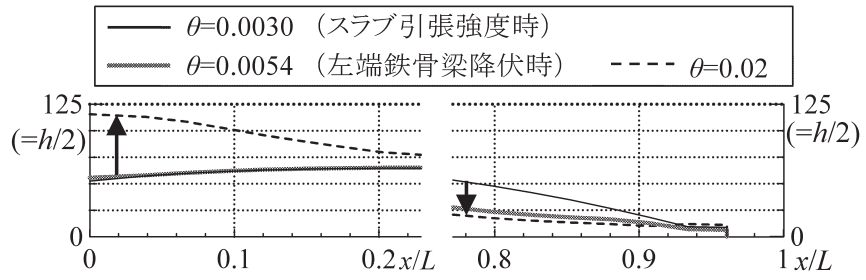

(b) 試験体 $5 \mathrm{~S}$

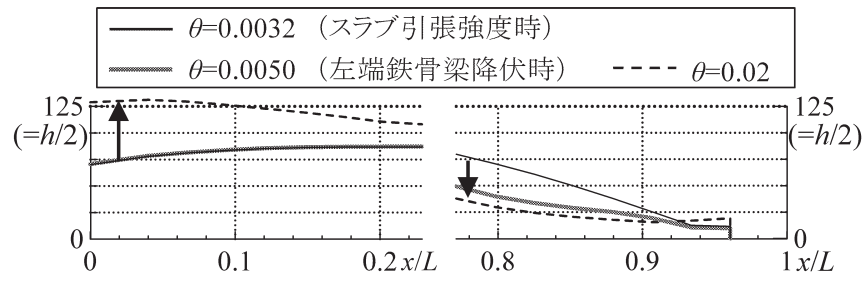

(c) 試験体 $10 \mathrm{~S}$

図 17 鉄骨梁図心を原点とした中立軸位置の分布と变化

この傾向は、 $\theta=0.02$ (破線) の左端から図中の灰色の破線までの領 域で確認される。鉄骨梁降伏時（灰色の実線）では、正曲げ区間の $q$ 分布は概社一定值を取る。一方、負曲げ区間の $q$ 分布はコンクリ 一ト引張強度に至った断面ではゼロ（式(2)）となり、右端ではスラ ブ要素が力を負担しないため、大きい值をとる。このため、全試験 体のスタッド要素が右端で降伏せん断力に達し（図 12 の(4)）、 $q_{y}$ の 小さい試験体 $5 \mathrm{~S}$ （2.1 節の表 4）では他の試験体よりも早期であっ た。さらに、試験体 $5 \mathrm{~S}$ は鉄骨梁降伏による $q$ の増大によって正曲 げ区間にあるスタッド要素が降伏する(図 12 の(5)。以上のように、 合成梁の構成部材の弾塑性挙動は、各部材の挙動が影響しあいなが ら変化する。

\section{4 梁端周辺における中立軸位置および歪の傾向}

図 17 に MS 要素から得た中立軸の位置（鉄骨梁図心を原点）の分 布と $\theta$ の増加による変化を示す。左端について、中立軸は、鉄骨梁 降伏時では鉄骨梁図心から梁せいの 2～3 割程度上の位置にあり、 $\theta=0.02$ ではほぼ上フランジに位置する。ただし、この中立軸の移動 は、梁端から離れた領域ほど小さい。なぜなら、端部に近いほど塑 性化が進行して、3.3 節で前述したようにスラブの寄与が大きいた めである。一方、右端ではスラブと梁端とが接触しないため、中立 軸は概数鉄骨梁図心にある。ただし、スラブ引張強度以前では梁の

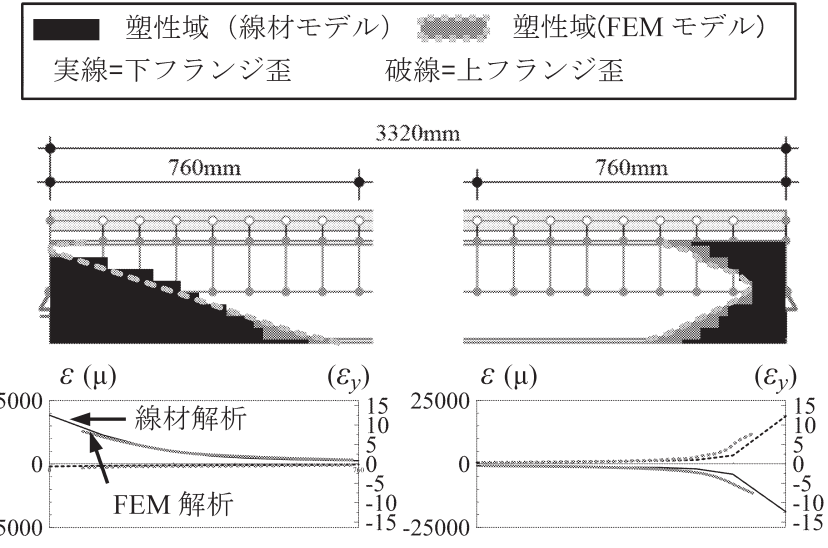

(a) 試験体 5D

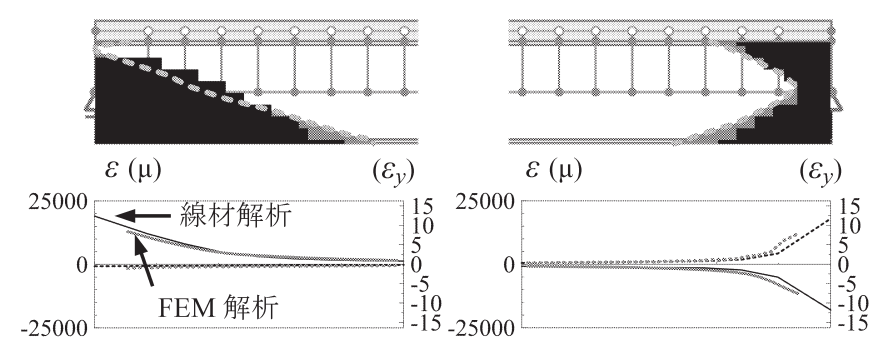

(b) 試験体 $5 S$
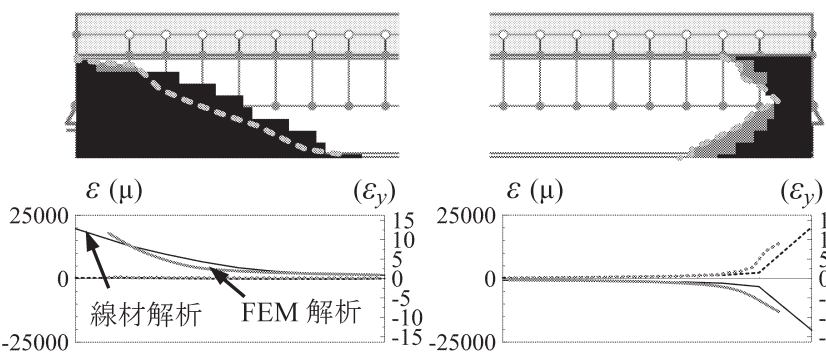

$\varepsilon(\mu)$

$\left(\varepsilon_{y}\right)$

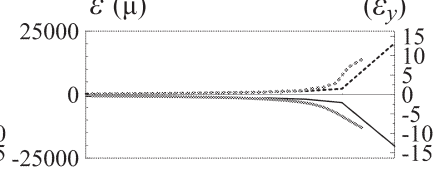

(c) 試験体 10S

図 $18 \theta=0.02$ での塑性域（上）と上下フランジの歪分布（下）

中央にいくにつれてスラブの寄与が大きくなるため、中立軸が上が る。なお、右側の中立軸が左端鉄骨梁降伏時から $\theta=0.02$ にかけて下 がる原因は、スラブが引張強度以上の応力を負担しないためである。

図 18 に $\theta=0.02$ における各試験体の梁端付近の鉄骨梁の塑性域と 上下フランジの材長方向の歪分布を FEM モデルの結果も併せて示 す。ここで、FEM モデルの梁材長方向の歪は、梁端では断面を剛と しているため、その付近では梁幅方向の歪が影響して小さくなるこ とを確認している。そのため、FEM モデルの歪值は、一軸歪状態が 確保される梁端から鉄骨梁幅の 6 割程度 $(81.25 \mathrm{~mm})$ 離れた断面まで を示す。線材モデルと FEM 解析モデルは、塑性域と歪分布が概补 対応していることが確認され、両解析モデルは局所的な挙動におい

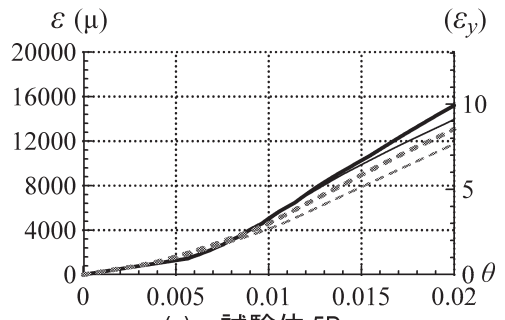

(a) 試験体 5D

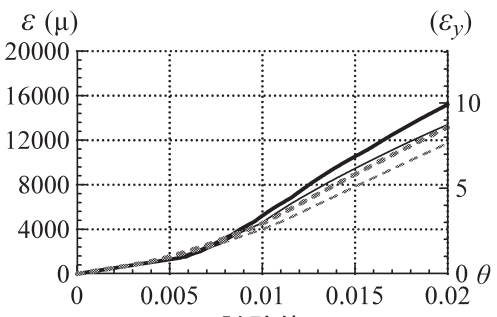

(b) 試験体 $5 \mathrm{~S}$

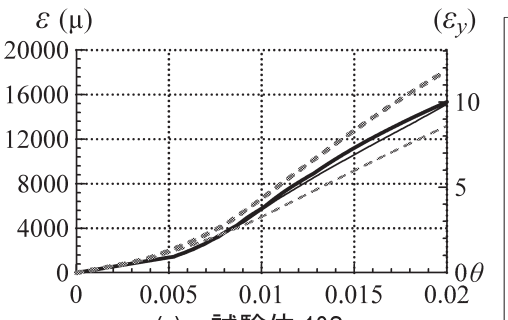

(c) 試験体 $10 \mathrm{~S}$

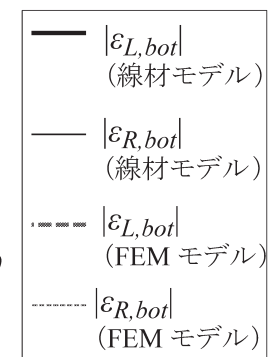

図 19 左右梁端付近における鋼梁下フランジ歪の推移 


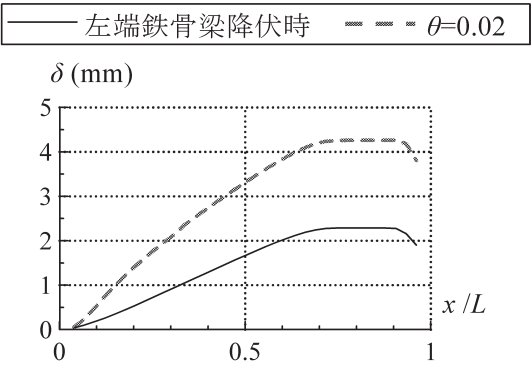

図 20 試験体 5D での鉄骨梁とスラブ の界面に生じるずれ

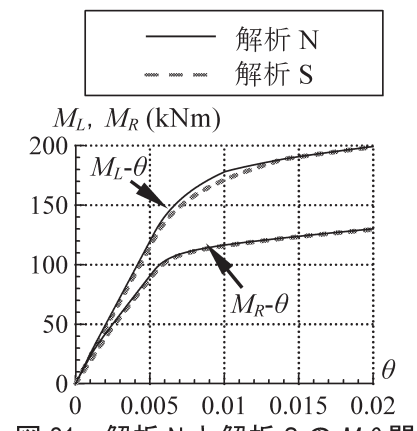

図 21 解析 $N$ と解析 $S$ の $M-\theta$ 関係 での比較（試験体 5D）
表 9 解析 N での状態変化が生じる $\theta$ と解析 S との比

\begin{tabular}{|l|l|l|l|}
\hline & 試験体 5D & 試験体 5S & 試験体 10S \\
\hline (1) & $0.0011,0.44$ & $0.0013,0.43$ & $0.0014,0.45$ \\
\hline (2) & $0.0054,1.00$ & $0.0053,1.00$ & $0.0050,1.00$ \\
\hline (3) & $0.0101,0.72$ & $0.0159,-$ & 0.0177, - \\
\hline (4) & $0.0008,0.04$ & $0.0007,0.11$ & $0.0010,0.06$ \\
\hline (5) & $0.0120,-$ & $0.0070,0.67$ & 0.0083, - \\
\hline
\end{tabular}

各番号は図 12 を参照

$\ulcorner ， 」$ 前は解析 $\mathrm{N}$ での $\theta$ 、後は解析 $\mathrm{S}$ での $\theta$ との比

ても整合するといえる。次に、線材モデルの結果に着目して、各試 験体の右側の塑性域は梁せい程度までの領域であるが、左側の塑性 域は右側の 2 倍程度の領域、寸なわち梁長さの約 $20 \%$ の範囲までに 至っている。歪分布をみると、鉄骨梁左側の歪分布は滑らかに変化 する。一方、鉄骨梁右側における歪分布は、右端とその直近のスタ ッド要素まで断面ではスラブの寄与がないため、それよりも内側の 断面よりも急激に変化し、端部では左端と同等の值となっている。 以上より、鉄骨梁の塑性化領域は、正曲げを受ける左側では比較的 長い範囲の下フランジ、負曲げを受ける右側では端部の上下フラン ジに集中すると言える。

図 19 に各試験体の左右端付近における下フランジ歪 $\varepsilon_{L, b o t}, \varepsilon_{R, b o t}$ の推移を絶対值で示す。ここでも、線材モデルと FEM モデルの結 果を示し、両者の比較のために、前者は梁端から鉄骨梁幅の 5 割程 度 $(65 \mathrm{~mm})$ 離れた断面、後者は 6 割程度 $(81.25 \mathrm{~mm})$ 離れた断面の歪值 を図示する。なお、前者について、対象とする断面の下フランジ歪 の值は、梁端の 0.8 倍程度である。FEM 解析に対する線材解析の歪 值は、弾性時ではほぼ一致し、 $\theta=0.02$ では試験体 $10 \mathrm{~S}$ の $\varepsilon_{L, b o t}$ で 0.85 倍、これ以外で概ね 1.15 倍であり、変形に対する梁端の歪挙動は概 ね対応していると言える。3.2 節で前述したように、鉄骨梁弾性時 の左右梁端下フランジは同等の歪值であり、ほぼ同時に降伏する。 また、鉄骨梁降伏後から $\theta=0.02$ でもほぼ同等の歪值である。なお、 ここでは左右の梁変形角を等しくしているが、架構における合成梁 は正曲げを受ける区間では負曲げを受ける区間よりも小さい梁変形 角のため、左端の歪值は右端に対してより小さい歪值になると考え られる。

\section{5 鉄骨梁とスラブの界面に生じるずれの影響に関する注䣋}

ここでは、前章の試験体 $5 \mathrm{D}$ を代表して、スタッド要素の剛性を 十分に高くして鉄骨梁とスラブの界面に生じるずれの生じさせない 解析（以下、解析 N) と前章までの解析（以下、解析 S) を比較し て解析 S でのずれの影響について言及する。

図 20 に解析 $\mathrm{S}$ でのスタッド変形の積分值として得たずれ $\delta$ を示 す。 $\delta$ はスラブ引張強度に達した断面 (図 16 中段) で最大值をとり、

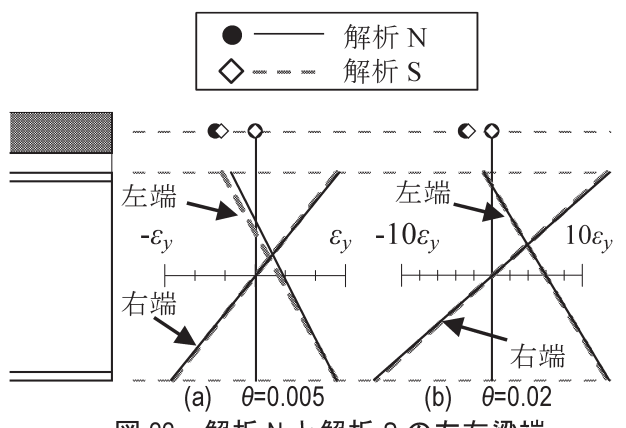

図 22 解析 $N$ と解析 S の左右梁端 での歪分布（試験体 5D）

その付近の右端ではスラブの梁端接触面との離間のためゼロになら ない。試験体 $5 \mathrm{D}$ は、設計指針 ${ }^{12}$ の耐力指標である完全合成梁に必 要なスタッド本数の 3 倍以上を有し、比較的小さい $\delta$ と考えられる。

両解析の全体挙動と局所挙動の比較のために $M_{L^{-}} \theta, M_{R^{-}} \theta$ 関係を図 21 、左右梁端の歪分布を図 22 に示す。解析 $\mathrm{S}$ に対する解析 $\mathrm{N}$ は、 $M_{L^{-}} \theta$ 関係の $K$ で $3 \%$ 大きい程度（図 21 )、鉄骨梁弾性時での左端の 歪分布で僅かに大きいスラブ歪、小さい曲率、高い中立軸を有する （図 22a）が、ほぼ一致している。表 9 に解析 N での各試験体にお ける状態変化が生じた $\theta$ と解析 $\mathrm{S}$ との比を示す。ずれを生じさせな いことは、スラブとスタッド要素の負担応力を大きくするため、そ れらの状態変化を早めるが、鉄骨梁の降伏には影響しなかった。

以上の他に、弾性・弾塑性時での材長方向の部材応力分布と歪の 局所挙動についても、ずれの影響は僅かであることを確認している。

4. 簡易な評価式による鉄骨梁弾性時での梁端下フランジ歪の分析 前章の解析では、正曲げ・負曲げを受ける両梁端の下フランジ歪 は同等であることを確認した。このことを平面保持を仮定した簡易 な評価式で表すことで一般的に生じうる現象であることを説明する。 なお、正曲げ・負曲げ長さは、前章では非線形解析の結果として求 められたが、ここではこれを解析的に求め、この結果を用いて歪も 陽な形式で表す。鉄骨梁弾性時を対象とするが、左右梁端の降伏す る順番を知ることができ、設計に有用であると考えられる。

\section{1 柱変形角を考慮したカ学モデルと合成梁の梁端歪算出方法}

図 23 に対象とする架構、図 24 に力学モデルの概要を示す。対象 とする架構は、上下の柱長さ半分を反曲点と仮定して抽出した架構 であり、層間変形 $\theta$ が作用寸る場合を考える。左右梁端に回転剛性 $K_{L}, K_{R}$ を有する回転ばねを配置することで柱変形角を再現する。 $K_{L}$, $K_{R}$ は次式で表す。

$$
K_{L}=12 \cdot \frac{E I_{s}}{L} \cdot \kappa, \quad K_{R}=\lambda \cdot K_{L}
$$

$\kappa$ は鉄骨梁に対する柱の剛比を表し、 $\kappa=\infty$ の場合は前章までのように 左右の梁変形角が等しい場合に相当する。 $\lambda$ は任意の正数である。

続いて梁端歪算出方法について述べる。正曲げ区間の梁長さを $a$, 断面 2 次モーメントを $I$ 、梁端下フランジの歪を $\varepsilon_{L, b o t 、}$ 負曲げ区間

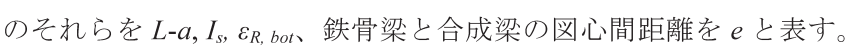
$I$ と $e$ は平面保持を仮定して次式で表せる。

$$
I=I_{S}+A_{s} \cdot e^{2}+A_{c} / n \cdot\left(D_{G}-e\right)^{2}, e=\frac{A_{c} / n}{A_{c} / n+A_{s}} \cdot D_{G}, A_{c}=B \cdot t \quad(4 \mathrm{a}-\mathrm{c})
$$

式(4a-c)で $I$ と $e$ が求まったことと、両区間の境界（即ち、反曲点） において変形の勾配が等しいことから、 $a$ が次式で表せる。 


$$
\begin{aligned}
& a=\frac{\bar{K}-\sqrt{\bar{K}^{2}-4 \bar{I}\left(L^{2} / I_{s}+2 E L / K_{R}\right)}}{2 \bar{I}} \\
& \bar{K}=\frac{2 E}{K_{L}}+\frac{2 E}{K_{R}}+\frac{2 L}{I_{s}}, \quad \bar{I}=\frac{1}{I_{s}}-\frac{1}{I}
\end{aligned}
$$

$(5 \mathrm{a}-\mathrm{c})$

式(4a-c)と(5a)で算出した $I, e$ と $a$ 、さらには両区間の梁せん断力 $P$ が等しいことから $\varepsilon_{L, \text { bot }} / \varepsilon_{R, b o t}$ は次式で表せる。

$$
\begin{aligned}
& \varphi_{L}=\frac{P a}{E I}, \quad \varepsilon_{L, b o t}=\left(\frac{h}{2}+e\right) \cdot \varphi_{L}=\left(\frac{h}{2}+e\right) \cdot \frac{P}{E I} \cdot a \\
& \varphi_{R}=\frac{P(L-a)}{E I_{S}}, \quad \varepsilon_{R, b o t}=\frac{h}{2} \cdot \varphi_{R}=\frac{h}{2} \cdot \frac{P}{E I_{s}} \cdot(L-a) \\
& \frac{\varepsilon_{L, b o t}}{\varepsilon_{R, b o t}}=\left(1+\frac{2 e}{h}\right) \cdot \frac{\varphi_{L}}{\varphi_{R}}, \quad \frac{\varepsilon_{L, b o t}}{\varepsilon_{R, b o t}}=\left(1+\frac{2 e}{h}\right) \cdot \frac{I_{s}}{I} \cdot \frac{a}{L-a}
\end{aligned}
$$

なお、式(3) (8) と解析 N の結果（3.5 節） が数值的に整合すること を確認している。以上のように、式(3)〜 (8)を用いれば、合成梁の断 面形状から正曲げ・負曲げ区間長さ $(a, L-a)$ が求まり、左右の梁端 下フランジの歪 $\left(\varepsilon_{L, b o t}, \varepsilon_{R, b o t}\right)$ とその大小関係が陽で表せる。

式( $8 \mathrm{~b})$ から $\varepsilon_{L, b o t} / \varepsilon_{R, b o t}$ は、鉄骨梁に対寸る合成梁の断面 2 次モーメ ントの比の逆数 $\left(I_{s} / I\right)$ により小さく、中立軸から下フランジまでの 距離の比 $(1+2 e / h)$ と梁端から反曲点までの長さの比 $(a /(L-a))$ に より大きくなることがわかる。また、3.5 節の解析 N の歪分布（図 22a）において、 $I_{s} / I$ と $a /(L-a)$ の積で表される曲率の比 $\varphi_{L} / \varphi_{R}($ 式(8a) が 1 以下であることが確認され、左端では右端より高い剛性によっ て曲率が小さいために、左右の梁端で下フランジ歪はほぼ同等とな っていることがわかる。つまり、複曲率曲げを受ける合成梁の検討 では、正・負曲げ区間の剛性の違いにより両区間で区間長さと変形・ 曲率が異なるため、1.1 節で述べたような、片持ち梁として同じ梁 長さの合成梁に正負同等の変形・曲率を交互に与えて得られる結果 と異なることに注意する必要がある。

\section{2 左右梁端の下フランジ歪の大小関係に関する考察}

式(3)から(8)を用いて定量的な考察を行う。図 25 に合成梁断面を 示す。典型的な合成梁を対象にして、鉄骨梁は H-600×250×12×22、 スラブは $t_{d}=75 \mathrm{~mm}, t=80 \mathrm{~mm}$ 、梁長さは $L=7010 \mathrm{~mm}$ とした。本節での

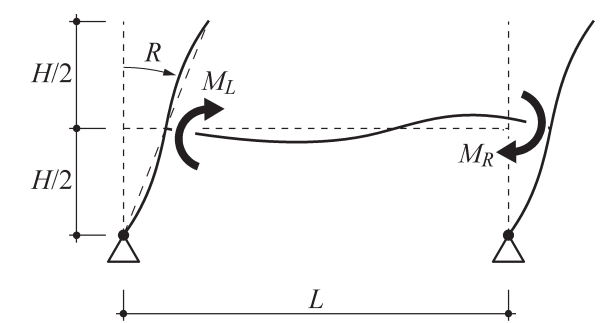

図 23 ラーメン架構の上下柱の長さ半分を抽出した架構

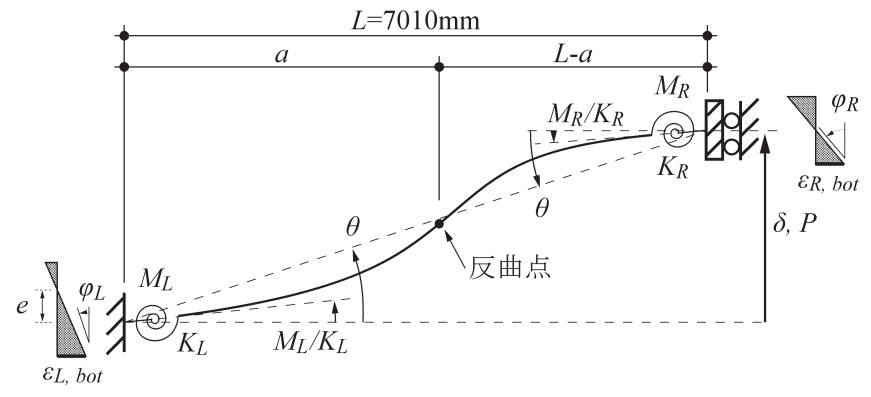

図 24 柱変形を回転バネで再現するモデルと左右梁端歪分布
み簡単のため、スラブは引張軸力を負担しない。これによって鉄骨 梁弾性時の $M_{R}$ と $\varepsilon_{R, b o t}$ は 0.9 倍程度になる。ここでは、正曲げ側と 負曲げ側の断面性能の差異が $\varepsilon_{L, ~ b o t} / \varepsilon_{R, b o t}$ に及ぼす影響を明確にする ために、明確な範囲をとる $e\left(0<e<D_{G}\right)$ を変数とした検討を行う。

図 26 に $2 e / h$ に対する $\varepsilon_{L, b o t} / \varepsilon_{R, b o t}, I_{s} / I, a /(L-a)$ を 4 種類の $K_{L}$ と $K_{R}$ の

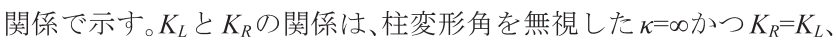
柱変形角を考慮した例として $\kappa=1$ かつ 1 スパン架構を想定した $K_{R}=K_{L}$ と、 2 スパン以上の架構の中柱と側柱の関係などを想定した $K_{R}=0.5 K_{L} 、 K_{R}=2 K_{L}$ とした。

図 26a d に共通して、2e/h が大きいほど $I_{s} / I$ は小さくなり、 $a /(L-a)$ は大きくなる。そして、これら 3 つの比の積で表せられる $\varepsilon_{L, b o t} / \varepsilon_{R, b o t}$ は、 $k=\infty$ (図 26a) では $2 e / h$ が大きいほど大きくなり、 $k=1$ (図 26b-d)

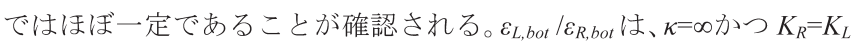
の場合（図 26a)、最大で 1.2 程度であり、左右梁端で下フランジの 歪值に大きな差異がないことがわかる。 $\kappa=1$ かつ $K_{R}=0.5 K_{L}$ の場合 (図 $26 \mathrm{~b})$ 、左端での $\theta$ に対寸る梁変形 $\left(\theta-M_{L} / K_{L}\right)$ が大きいため、 $a /(L-a)$ が 1.1 2.0 と他の $\kappa=1$ の場合（図 26c, d）と比較して大きな值をとる が、 $\varepsilon_{L, b o t} / \varepsilon_{R, b o t}$ は 1.1 1.2 と左右梁端で下フランジの歪值に大きな差 異がない。 $\kappa=1$ かつ $K_{R}=K_{L}$ および $K_{R}=2 K_{L}$ の場合 (図 $26 \mathrm{c}, \mathrm{d}$ )、 $\varepsilon_{L, b o t} / \varepsilon_{R, b o t}$ は前者ではほぼ 1 であり、後者では常に 1 以下であることが確認さ れる。

以上のように、3 章で述べた正曲げ・負曲げを受ける両梁端の下 フランジ歪が同等となることを簡易な解析により確認し、3 章での 結果が一般的に成り立つことを確認した。ただし、本章では平面保 持を仮定し、かつスラブの引張力負担を無視した簡易な検討である。 ずれとスラブの引張力負担を考慮したより詳細な検討は次章で行う。

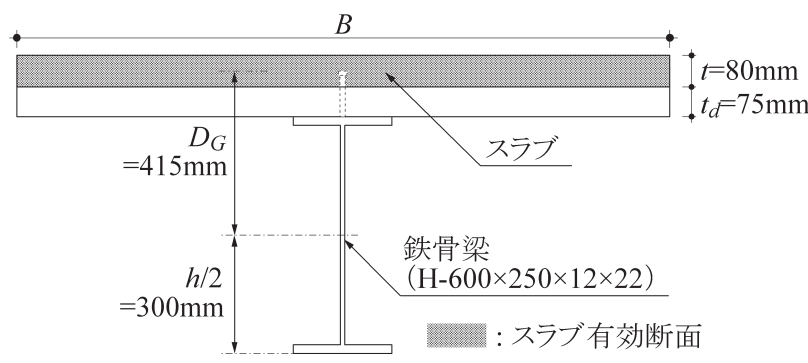

図 $25 \quad 4.2$ 節と 5 章で対象とする合成梁

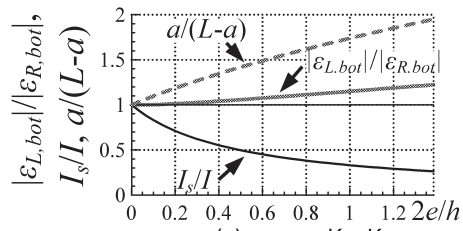

(a) $\kappa=\infty, K_{R}=K_{L}$

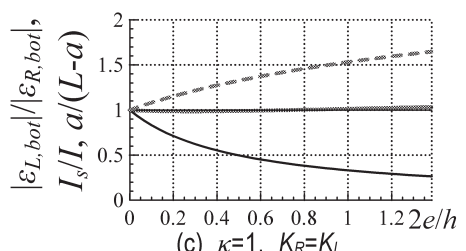

(c) $K=1, K_{R}=K_{L}$

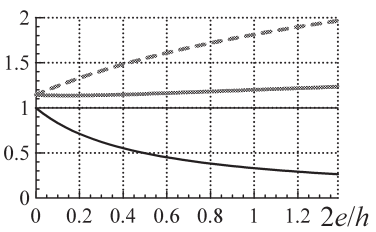

(b) $\kappa=1, K_{R}=0.5 K_{L}$

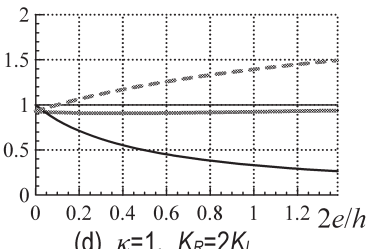

(d) $\kappa=1, K_{R}=2 K_{L}$

図 26 任意の $K_{L}, K_{R}$ に対して中立軸位置 $2 \mathrm{e} / \mathrm{h}$ が左右の梁端下フラ ンジ歪、区間長さ、断面 2 次モーメントの比に及ぼす影響 
5. ずれと柱変形角が梁端のモーメントと下フランジ歪に及ぼす影響

\section{1 柱変形角を考慮した解析モデルへの拡張}

本章では、本解析モデル（図 4）を図 24 の力学モデルに拡張し、 左右梁端の下フランジ歪の大小関係について詳細な分析を行う。こ

こでの分析は、ずれと柱変形角が梁端の下フランジ歪とモーメント に与える影響を明らかにするために、柱梁剛比 $\kappa$ とずれ剛性 $k$ を変 数とし、鉄骨梁降伏後を含めたものである。なお、 $k$ は $K_{s t}$ を配置間 隔で除した値である。

合成梁断面は 4.2 節で示した図 25 と同じとして、スラブ幅 $B$ は設 計指針 ${ }^{12}$ より $1652 \mathrm{~mm}$ とした。表 10 に鉄骨梁の各種性能を示す。 ウェブとフランジは $490 \mathrm{~N}$ 級を想定し、その降伏応力は公称值の 1.1 倍に相当する $360 \mathrm{~N} / \mathrm{mm}^{2}$ とした。

表 10 本章で用いる鉄骨梁の各種性能

\begin{tabular}{|c|c|c|c|c|c|}
\hline $\begin{array}{c}\text { 断面積 } \\
A_{s}\left(\mathrm{~mm}^{2}\right)\end{array}$ & $\begin{array}{c}\text { せん断 } \\
\begin{array}{c}\text { 断面積 } \\
A_{s h}\left(\mathrm{~mm}^{2}\right)\end{array}\end{array}$ & $\begin{array}{c}\text { 断面 2 次 } \\
I_{s}\left(\mathrm{~mm}^{2}\right)\end{array}$ & $\begin{array}{c}\text { 降伏軸力 } \\
N_{s y}(\mathrm{kN})\end{array}$ & $\begin{array}{c}\text { 降伏 } \\
\text { モメト } \\
M_{s y}(\mathrm{kN} \cdot \mathrm{m})\end{array}$ & $\begin{array}{c}\text { 全塑性 } \\
M_{s p}(\mathrm{kN} \cdot \mathrm{m})\end{array}$ \\
\hline 17820 & 6672 & $108800 \times 10^{4}$ & 6362 & 1321 & 1478 \\
\hline
\end{tabular}

5. 2 正曲げ側の梁変形角が負曲げ側よりも大きい場合の検討

$K_{R}=0.5 K_{L}$ の関係を例にして、正曲げ側の梁変形角が負曲げ側より も大きく、早期に降伏し得る場合を対象にした検討を行う。柱梁剛 比とスタッド要素の剛性は、典型的な例としてそれぞれ $\kappa=2, k=2$ (3 章でのスタッド要素の剛性) とする。

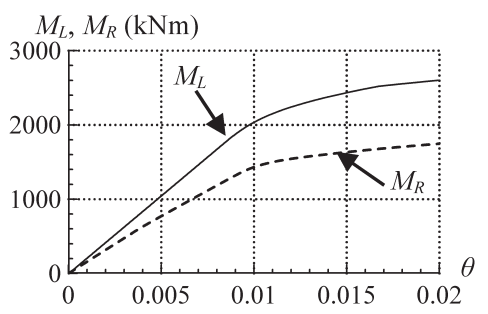

(a) 左右端のモーメントの推移

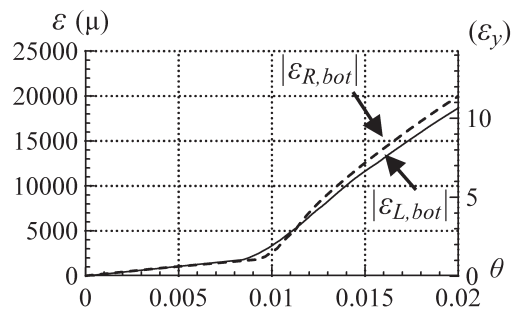

(b) 左右端の梁下フランジ歪の推移
図 27 に $M_{L}, M_{R}$ および $\varepsilon_{L, b o t}, \varepsilon_{R, b o t}$ の推移を示す。図 $27 \mathrm{a}$ から、 $M_{L}$ は $M_{R}$ よりも常に大きく、弾性時では 1.32 倍、 $\theta=0.02$ では 1.49 倍で ある。図 $27 \mathrm{~b}$ の $\varepsilon_{L, b o t}$ は、図 $27 \mathrm{a}$ で確認された $M_{L}$ の増大に対して小 さく、 $\varepsilon_{R, b o t}$ とほぼ同等と言える。なお、 $\varepsilon_{L, b o t} / \varepsilon_{R, b o t}$ は、弾性時で 1.07 倍、 $\theta=0.02$ で 0.94 倍である。本節では一例として任意の $K_{L}, K_{R}, \kappa, k$ を仮定したが、次節ではこれらのパラメトリックスタディによって 下フランジ歪の挙動を包括的に捉える。

\section{3 多様な柱梁剛比とずれ剛性の組み合わせが下フランジ歪に及ぼ す影響の分析}

図 28 に 10 種の $\kappa$ と 8 種の $k$ に対する $M_{L} / M_{R}, \varepsilon_{L, b o l} / \varepsilon_{R, b o t}$ の関係を、 3 種の $K_{L}$ と $K_{R}$ の関係について鉄骨梁弾性時の $\theta=0.005$ で示す。また、 横軸には左端から反曲点までの距離 $a$ を梁長さ $L$ で除した值を併せ て示す。図中の破線は純鉄骨梁の場合の関係であり、 $k=0.0001$ $\mathrm{kN} / \mathrm{mm} / \mathrm{mm}$ での結果はこの線上に収束し、 $k \geqq 0.0001 \mathrm{kN} / \mathrm{mm} / \mathrm{mm}$ での 結果はこの線より下に位置する。これは、 4.3 節で前述したように、 合成梁の下フランジに生じる歪は、同じモーメントの作用する純鉄 骨梁に対し、中立軸の上への移動による増大よりも、断面 2 次モー メントの増大による減少を大きく受けるためである。

図 $28 \mathrm{a} K_{R}=0.5 K_{L}$ では、 5.2 節で述べたように、正曲げ側の梁変形角 $\theta_{L}$ は柱変形によって負曲げ側の梁変形角 $\theta_{R}$ より大きいため、

$\varepsilon_{L, b o t} / \varepsilon_{R, b o t}$ は 1 より大きい傾向にある。 $\varepsilon_{L, b o t} / \varepsilon_{R, b o t}$ は、 小さくなり、 $k=1$ 以上かつ $k=1 \mathrm{kN} / \mathrm{mm} / \mathrm{mm}$ 以上で は $\varepsilon_{L, b o t} / \varepsilon_{R, b o t}$ は 1.1 以下である。つまり、正曲げ側 の梁変形角が負曲げ側より大きい場合でも、典型 的な柱梁剛比とスタッド要素の剛性であれば、左 右梁端の鉄骨梁はほぼ同等に降伏寸ると言える。

図 $28 \mathrm{~b}$ の $K_{R}=K_{L}$ と図 $28 \mathrm{c}$ の $K_{R}=2 K_{L}$ では、 $\varepsilon_{L, b o t} / \varepsilon_{R, b o t}$ は 1 より小さい傾向にある。 $\varepsilon_{L, b o t} / \varepsilon_{R, b o t}$ は、 $\kappa$ が大 きいほど大きく、 $k=0.1 \mathrm{kN} / \mathrm{mm} / \mathrm{mm}$ で最大值 1.1 を とり、 $k \geqq 1 \mathrm{kN} / \mathrm{mm} / \mathrm{mm}$ では $\kappa$ のきさに関わらず
図 $27 \quad K R=0.5 K L$ の場合、 $k=2 、 k=2$ での左右端のモーメントと下フランジ歪の推移

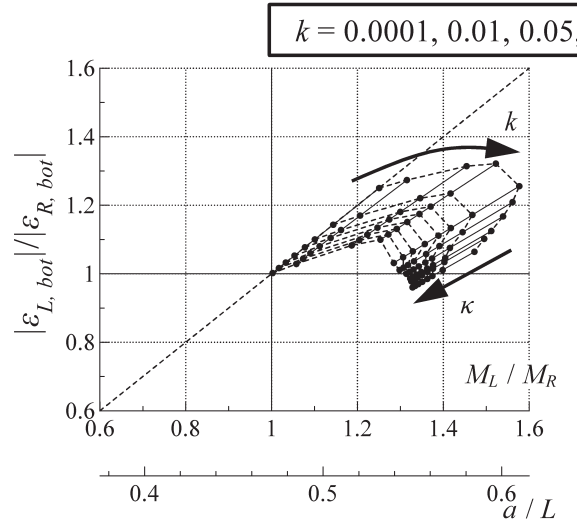

(a) $K_{R}=0.5 K_{L}$ の場合

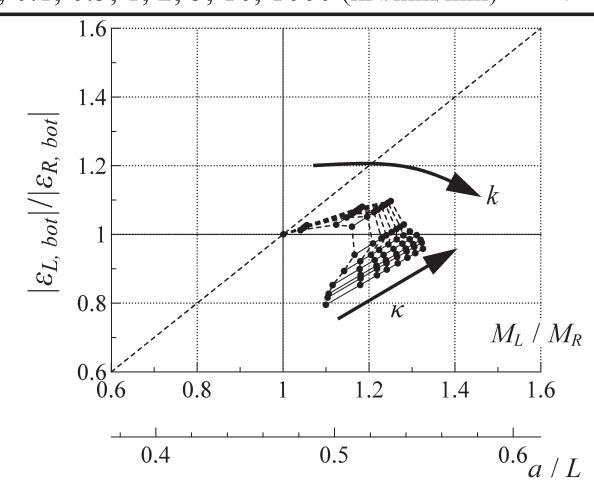

(b) $K_{R}=K_{L}$ の場合

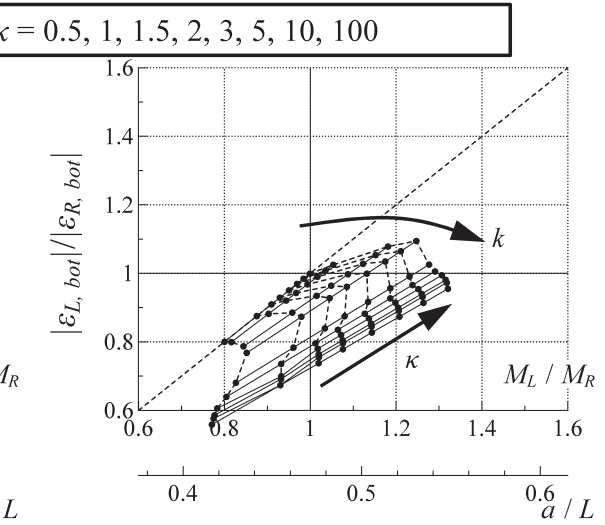

(c) $K_{R}=2 K_{L}$ の場合
図 $28 \theta=0.005$ での $\kappa$ と $k$ に対する $M_{\llcorner} / M_{R},\left|\varepsilon_{L, \text { bot }}\right| /\left|\varepsilon_{R, \text { bot }}\right|$ の関係

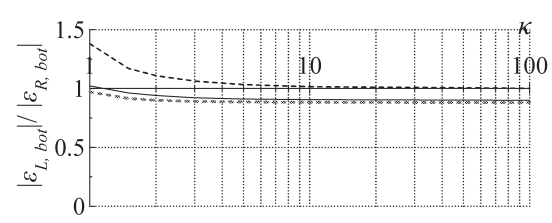

(a) $K_{R}=0.5 K_{L}$ の場合

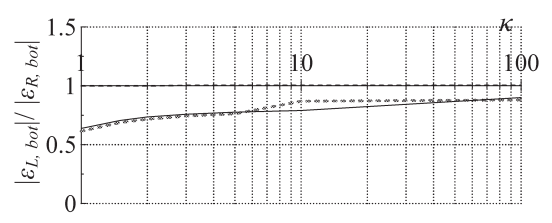

(b) $K_{R}=K_{L}$ の場合

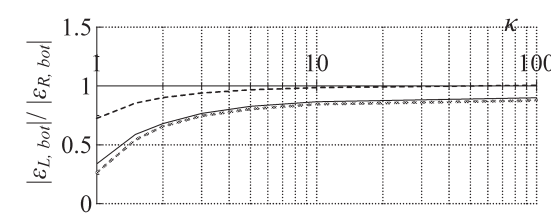

(c) $K_{R}=2 K_{L}$ の場合
図 $29 \theta=0.02$ での $\kappa$ に対する $\left|\varepsilon_{L}\right| /\left|\varepsilon_{R}\right|$ の関係 $(---$ - $k=0.000$

$-k=1000$ ) 
1 以下である。これらは、柱変形によって正曲げ側の梁変形角が負 曲げ側よりも小さくなること、および 5.2 節で前述したごとくモー メントの増大に対して下フランジ歪の増大は小さいという関係から 説明できる。以上より、 $K_{R}=K_{L}$ 、および $K_{R}=2 K_{L}$ の関係では、負曲げ 側の梁端の鉄骨梁が先行して降伏し易いと考えられる。

図 29 に $\theta=0.02$ での $\kappa=1$ 以上と 3 種の $k$ に対する $\varepsilon_{L, b o t} / \varepsilon_{R, b o t}$ の関係 を示す。 $\theta=0.02$ では、 $K_{R}=0.5 K_{L}$ における極めて小さい $k$ の場合を除 いて、 $\varepsilon_{L, b o t} / \varepsilon_{R, b o t}$ は 1 以下で、 $\theta=0.005$ 時よりも小さい。以上のよう に、典型的な $\kappa$ と $k$ を有していれば、正曲げを受ける梁端の下フラ ンジ歪は負曲げ側とほぼ同等であることを鉄骨梁の弾性・塑性時に おいて確認した。

\section{6. まとめ}

複曲率曲げを受ける合成梁を対象として、既往の実験結果を再現 できる解析モデルを作成し、鉄骨梁・コンクリートスラブ・スタッ ドの弾塑性挙動、梁端およびその周辺の歪挙動について分析を行な った。さらに、架構における合成梁を対象として、柱変形が合成梁 の局所挙動に及ぼす影響についても考察した。以下に、要約する。

(1) 合成梁の主要構成部材である鉄骨梁・スラブ・スタッドを線 材要素・マルチスプリング要素により再現した解析モデルと詳細な 有限要素解析モデルは、既往実験における梁端モーメント - 梁変形 角関係の荷重変形関係を精度よく再現できることを示した。

（2）本解析モデルは、実験では計測できなかった、梁端および材 長方向での上記の主要構成部材単位での負担応力やそれらの伝達、 および歪などの局所挙動を比較的簡易に把握寸ることができるため、 有限要素解析に比心゙設計に有用である。

（３）合成梁構成部材の応力・歪は、各部材の弾塑性挙動の影響を 受けて大きく変化する。中でも、鉄骨梁の降伏は、梁端モーメント 一梁変形角関係の勾配を低下させ、正曲げを受ける区間でのスラブ とスタッドの応力を増大させる。

（4）既往実験を対象にした解析では、左右梁端の下フランジはほ ぼ同時に降伏した。片持ち梁として同じ梁長さの合成梁に正負同等 の変形および曲率を与える場合では正曲げ時の下フランジ歪が大き くなるが、複曲率を受ける合成梁については、正曲げ側では高い剛 性によって小さい曲率となるため前述した結果が得られた。この要 因と影響を簡易な評価式によるパラメトリックスタディにより明ら かにした。

（5）弾性時における負曲げ側に対する正曲げ側梁端の下フランジ 歪の比は、断面 2 次モーメントの比の逆数、中立軸位置の比、梁端 から反曲点までの長さの比の 3 つの係数で表せることを示した。さ らに、梁端から反曲点までの長さを柱変形角による影響を考慮した 簡易な計算式で表すことで、左右梁端の下フランジ歪の大小関係を 把握できる有用な検討方法を示した。

（6）既往実験では含まれていない、柱変形によって左右梁端の梁 変形角が異なる場合を分析するために、本解析モデルを拡張して、 正・負曲げ側の下フランジ歪の大小関係を検討した。この分析より、 正曲げ側の梁変形角が大きい場合でも、典型的な柱梁剛比とスタッ ド剛性を有していれば、左右梁端の下フランジ歪が同等であること を確認した。

\section{謝辞}

本論文で用いた実験データは、京都大学井上一朗名誉教授に提供 していただきました。査読者の方々からは大変貴重な意見を賜り、 論文を大きく改善することができました。ここに感謝の意を表しま す。

\section{参考文献}

1) 五十嵐定義, 井上一朗, 金 成垠, 多田元英 : 合成梁部材の弾性剛性及 び終局耐力に関する解析的研究, 日本建築学会大会学術講演梗概集, pp.393-396, 1981.6

2) 井上一朗，金 成垠，五十嵐 定義 : 合成ばりの弾性剛性と終局曲げ而 力に関寸る実験的研究, 日本建築学会論文報告集 第 344 号, pp.68-80, 1984.10

3) 石川孝重, 平野道勝 : 水平繰り返し外力が作用寸る合成梁の二次元弾 塑性解析，構造工学論文集 Vol.31B，pp. 183-196，1987.8

4) 山野辺宏治, 矢部喜堂, 和田章: 3 スパン連続合成梁を有する鉄骨骨組 の水平加力実験, 日本建築学会構造系論文集 第 487 号, pp.121-129, 1996.9

5) M. Tada, H. Tamai, K. Ohgami, S. Kuwahara, A. Horimoto : Analytical simulation utilizing collaborative structural analysis system, The 14th World Conference on Earthquake Engineering, CD-ROM， 2008.8

6) 松宮智央, 中島正愛, 吹田啓一郎, 佐藤有希：梁の損傷特性と床スラ ブとの合成効果，実大 3 層鋼構造骨組を用いた耐震性能実証実験，日 本建築学会構造系論文集 第 593 号, pp.177-184, 2005.7

7) 吹田啓一郎，松岡祐一，山田哲，島田侑子，多田元英，笠井和彦：震 動台実験の概要々弹性応答特性, 実大 4 層鉄骨造建物の完全崩壊実験 その 1, 日本建築学会構造系論文集 第 635 号, pp.157-166, 2009.1

8）笠井和彦，引野剛，伊藤浩司，大木洋二，元結正次郎，加藤史人，馬 場勇輝 : 実験の全体概要および非制振状態での応答性状, 3 次元震動台 による実大 5 層制振鋼構造建物の実験研究 その 1 , 日本建築学会構造 系論文集 第 663 号, pp.997-1006, 2011.5

9) 岡田健, 点相勲, 山田哲, 今枝知子, 山口路夫, 和田章 : 従来型の柱 梁接合部を有する合成梁の変形能力に関寸る実験的研究，合成梁の変 形能力を反映した鋼構造骨組の耐震性評価 その 1 , 日本建築学会構造 系論文集 第 547 号, pp.161-168, 2001.9

10) 酒井新吉, 元結正次郎，笠井和彦：コンクリートスラブを有する合成 梁および鉄骨架構の有限要素モデルの構築，構造工学論文集 Vol.58B, pp.423-428, 2012.3

11) 中原寛章，小川厚治：繰り返し荷重を受ける合成梁の弾塑性解析法に 関寸る研究，鋼構造論文集 第 14 巻 第 55 号, pp.99-110, 2007.9

12) 日本建築学会 : 各種合成構造設計指針・同解説，2010

13）日本建築学会：鋼構造塑性構造設計指針・同解説，2011

\section{付録 有効幅の検討}

実験データ（あるいは FEM 結果）からコンクリートスラブの有効幅を次の ように求めた。

図 A1 に示すような複曲率曲げを受ける梁を曲げ剛性の異なる正曲げ部、負 曲げ部の 2 本に分けた梁要素でモデル化する。この梁の両端に同じ回転を加 えたときの両端の曲げモーメントを求めることにより、両端の回転剛性が得 ることができる。

図 A1 のモデルの断面 2 次モーメントとして、正曲げ部には有効幅を仮定 した合成梁の正曲壮断面 2 次モーメント $I_{L 、}$ 負曲げ部には鉄骨梁の断面 2 次 モーメント $I_{R}$ を用いて求めた両端の荷重変形関係が、鉄骨梁塑性開始までの 実験デー夕（あるいは FEM 結果）のものと一致するように有効幅を最小二乗 法で定めた。

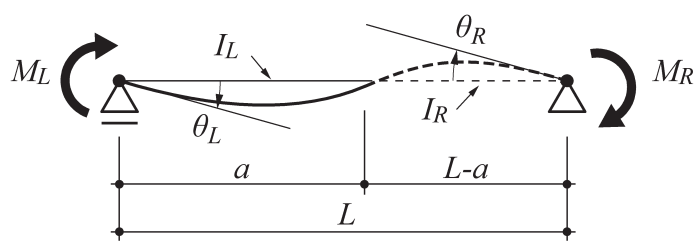

図 A1２ 要素による複曲率曲げ合成梁のモデル化 


\title{
BASIC STUDY ON BEHAVIOR OF COMPOSITE BEAM SUBJECTED TO DOUBLE CURVATURE BENDING
}

\author{
Yoriyuki MATSUDA*, Kazuhiko KASAI ${ }^{* *}$, Shinkichi SAKAI*** \\ and Shojiro MOTOYUI ${ }^{* * * *}$ \\ * Grad. Stud., Tokyo Institute of Technology, M.Eng. \\ ** Prof., Str'l Eng. Research Center, Tokyo Inst. of Technology, Ph.D. \\ *** Grad. Stud., Tokyo Institute of Technology, M.Eng. \\ (Itochu Techno-Solutions Corporation) \\ **** Prof., Dept. of Built Environment, Tokyo Institute of Technology, Dr.Eng.
}

Composite beam in a frame subjected to story drift consists of two portions of positive and negative bending moments, respectively. The lengths and moment magnitudes of the two portions are different due to the composite action and increased bending stiffness caused by positive bending. Thus, in order to understand the composite beam behavior, it is necessary to consider interaction between the two portions. This paper, therefore, proposes a practical analysis method to simulate in detail the behavior of a steel beam, a concrete slab, and stud connectors, and uses it to clarify the interaction as well as the composite action of the beam in double curvature bending.

Two types of composite beam models are used. One consists of multi-spring element, truss element, and beam element. Another is a FEM model that simulates nonlinear behavior of both steel and concrete. Both models simulate slip between the concrete slab and steel beam, bending of stud connectors, compression and tension failure of concrete slab, contact and separation between the slab and beam end, and yielding of the steel beam. Analysis results are compared with the past test result of composite beam subjected to double curvature. Two analysis models reproduced initial stiffness, strength, and moment-rotation curves of the test result with excellent accuracy (Fig.11 and Table 7). The analyses also gave more insight into the complex behavior of the composite beam subjected to the double curvature bending of various magnitudes, which are discussed below:

The steel beam of beam ends subjected to the same rotation, the beam end under positive bending and that under negative bending yielded almost at the same time (Fig.15). Shear force of a stud connector in a beam portion of positive bending grow larger when the steel beam yields there. On the other hand, it decreased when the concrete slab crashes there. The yield zone of the steel beam was concentrated into the bottom flange the case of positive bending, and it was over all the cross section in the case of negative bending (Fig 18). From elastic loading to inelastic loading exhibiting the beam rotation $\theta=$ 0.02 , bottom flange strains at both ends of the beam were about equal (Fig 19).

In case of composite beam subjected to double curvature, a ratio of bottom flange strains of the two beam ends under positive and negative bending, respectively, appears to be proportional to inverse of the ratio of moment inertia, the ratio of neutral axis distance from the bottom flange, and a ratio of portion length (Eqs. 5b). From elastic loading to inelastic loading exhibiting the beam rotation $\theta=0.02$, the bottom flange strain ratio is about 1.0 , which agrees with the analysis result. This cause is because the beam deflects relatively less under positive bending, and beam curvature grows in negative moment.

The effect of rotational restraint provided by the columns at the both ends of the beam is examined. Because the restraint is larger at the exterior column where only one beam is connected, the bottom flange strain tends larger. However, at $\theta=0.02$ and larger, curvature increase of the end under negative bending is remarkably large, which limits strain of the positive bending side. The exterior column case mentioned above as well as a single span case show that bottom flange strain of the beam in positive bending and thus composite action tends to be smaller than in negative bending. 